Factors affecting teachers' willingness of teaching social studies online after the Pandemic of CORONA: A Prospective Study

Dr. Abdullah Alhajri *

\title{
Abstract
}

The present study examined social studies teachers' willingness to pursue online teaching in the future. It also examined what factors affect such willingness, as well as the difference in this willingness. The researcher administered a questionnaire of 37 statement items on a sample of 283 Kuwaiti social studies teachers of both genders. The results showed that the sample teachers did indicate a steep willingness. However, it also demonstrated that the factors related to the learning environment were the most deterring ones. The differences between male teachers and females did not exist in the present study. The researcher concluded the study with some suggestions and recommendations concentrating on improving social studies teachers' willingness to online teaching that can warrant conclusive education of the students.

Keywords: online teaching, social studies teachers, teachers' willingness, affecting factors.

العوامل المؤثرة يُّة رغبت المعلمين بتدريس مادة الدراسات الاجتماعيتَ عبر الأنترنت بعد الانتهاء جائحت الكورونا:

دراست تامليت.

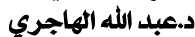

المستخلص

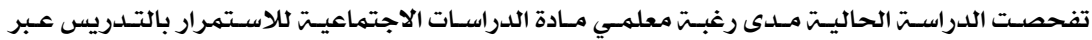

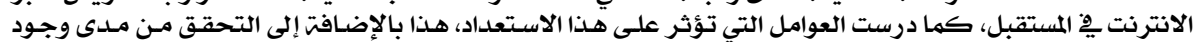

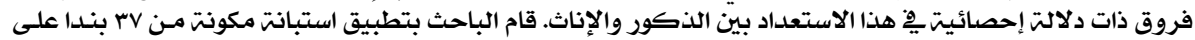

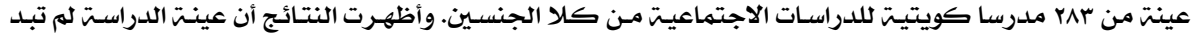

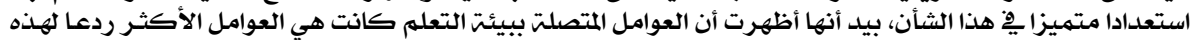

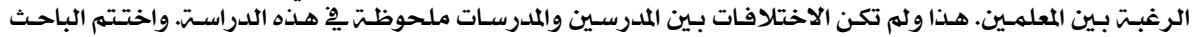

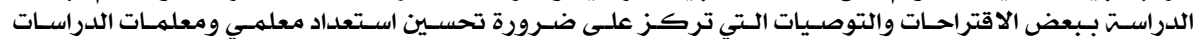

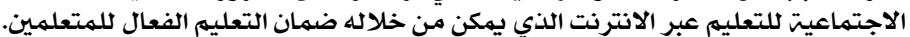

Introduction

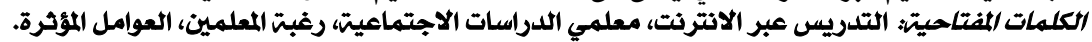

Since the advent of recent technological developments in the few elapsing decades, the world population has become more able to avail such revolutionary machines in every household and every room for its affordable costs to every human being worldwide. This affordance, of course, comes with some limitations, depending on the individual's financial resources, which determine the limited machine technical specifications of which they get hold. Some educational institutions have considered the utilization of these devices in the classrooms at an early stage. This utilization was in the blended learning form, the physical classrooms, and the online form simultaneously. However, the switch to complete utilization of online learning was not typical at that stage. Most of the educational institutions all around the globe were still

-Associate Professor, Department of C\&I, Kuwait University (Social Studies). 
sticking to the traditional educational process inside their buildings. That was probably because the need for a complete transition from formal face-to-face learning to online learning was not present yet. However, it has become gradually more popular among students worldwide due to the benefits seen by some to transcend that of the old learning system. Students have performed as well as or better than those in the traditional classrooms (Hiranrithikorn, 2019).

Like many other Gulf countries, Kuwait has been trying to reform its educational system by incorporating Information \& Communication Technologies (ICT) into the curriculum to meet the needs of the 21st Century society (Alrasheedi, 2009, p. 65). Nevertheless, the use of the available computers in the labs and staff rooms was minimal. For generations, the primary educational delivery model for Kuwait university faculty members was essentially the traditional lecture. However, due to revolutionary changes in information and communication technologies, knowledge delivery modules have been changed to include e-learning (Al-Fadhli, 2008, p. 1).

Every school felt the need for the transition to e-learning with the advent of Covid-19. However, countries' responses to the educational shock varied from one country to another (Alhouti, 2020, p. 213). That happened mainly in the regions where academic personnel did not pay attention beforehand to online learning. Kuwait falls under the group of these regions.

"School from home during the Covid-19 Pandemic has significantly impacted all countries in the world." Almost all countries implemented online learning systems (Aliyyah, Rachmadtullah, Samsudin, Syaodih, Nurtanto, \& Tambunan, 2020, p. 103). In 2020, every university had to switch to online education due to quarantine (Mirkholikovna, 2020). Kuwait is one of these countries. It went through partial and complete lockdowns between May and August 2020 following the significant "increase in cases and deaths in March and April 2020" (Alali, AlFouzan, Al-Tawalah, Kheirallah, \& Yimer, 2021, p. 4). Its schools and higher education institutions had to cease and discontinue until implementing the online form of education was taken. Failing to provide students with the opportunity to learn this process took not less than four months to prepare and acquaint everybody involved with that new-to-them type of education's requirements (Alhouti, 2020). Those included instructors, students, and parents. 
This new experience seemed to get some approval in much research (Hannay \& Newvine, 2006). It was perceived positively by most of the 256 student participants in Dung's (2020) study (Dung, 2020, p. 47). Many students prefer its continued implementation (Khan, Nabi, Khojah, \& Tahir, 2021, p. 13). Some Kuwaiti learners have shown the same preference and approval. They expressed their approbation stand towards it (Almisad \& Alsalim, 2020; AlSaeedi, 2021; Alali, AlFouzan, Al-Tawalah, Kheirallah, \& Yimer, 2021). Other students, meanwhile, did not consent to it. Instead, they expressed negative opposing stances and expressed their need for more supplements and support. They consider Kuwait still newborn in using technology in education (Al-Ajmi \& Aljazzaf, 2020, p. 229).

The Covid-19 Pandemic seems to continue longer, affecting educational institutions (Kimura, 2020). These institutions' tendencies towards the complete transition to online education have stupendously grown in many regions. Research has proved it to hold several positive advantages, especially its economic aspect. Chen's (2012) study results have indicated that "Webbased learning is helpful" had the highest value in the sample teachers' perceptions. The researcher then concluded that "when teachers apply webbased learning and realize its value to students, and when students interact with teachers through web-based learning, the willingness of teachers to use web-based learning may increase." (Chen, 2012, p. 4).

Chen's (2012) study concentrated on why teachers showed a willingness to teach online. In concluding that research, this researcher called for further study to investigate the reasons behind teachers' unwillingness to use web-based learning. (Chen, 2012, p. 5). The present study, then, aims to shed light on the perceptions of social studies teachers regarding their willingness to teach online before recommending further steps for such decisions.

\section{Significance of research}

Interest in online teaching has become widespread, specifically with the escalation of the Pandemic. Many studies examined the subject in many schools worldwide. Other studies were covering the willingness of teachers to switch to it from the in-building form of teaching. Nevertheless, very few have covered Kuwaiti schools. Since these studies' results might not reflect situations in all countries, developed and less developed (Kimura, 2020), and since none 
have covered the topic in Kuwait, the present study should contribute to that body of research by covering the same issue in this region.

The world of education is seemingly switching to more online learning for its broad benefits. Attending this region to investigate this learning's relativity should sharpen the decisions related to publicizing online education into Kuwaiti institutions' educational environments. That should be through examining teachers' willingness to teach online, which Chen's (2012) study suggested, may increase when teachers realize its value to students (Chen's, 2012, p. 4).

This research's results and recommendations should guide building the most favorable grounds for a successful online education implementation. Teachers' willingness, or maybe, unwillingness to teach online, is one of these grounds.

\section{Statement of the Problem}

The literature has shown how the Corona Covid -19 Pandemic has paralyzed the universe in every aspect. That began from the end of 2019 up to the present. That encompassed the schools which had to resort to internetbased educational technologies all along with this epoch.

The literature has shown that students perform as well as or better than those in the traditional classrooms (Hiranrithikorn, 2019). So, some educational institutions already shifted towards online education even before the advent of this Pandemic. Moreover, because of the many practical benefits of online learning during that Pandemic, other educational institutions consider taking a similar shift. As a result, some predict it to become the dominant form of education globally (Radović-Marković, 2010, p. 296).

Before making such decisions to such a shift in the Kuwaiti situation, we need to examine the willingness of Kuwaiti teachers, specifically of the social studies, and the factors affecting such willingness.

\section{Study purposes}

The present study's primary purpose is to target the teachers' perceptions of the advantages and disadvantages of teaching online. Out of that primary purpose, the study objectives are to:

1- Investigate the Kuwaiti social studies teachers' willingness of their future adoption of online teaching. 
2- Investigate the factors that affect Kuwaiti social studies teachers' willingness to future adopt online teaching.

3- Investigate the effect of Kuwaiti social studies teachers' gender on their willingness of future adopt online teaching.

\section{Study questions}

This research attempts to answer the following questions:

1- What is Kuwaiti teachers' willingness to teach social studies online after the CORONA pandemic?

2- What factors affect Kuwaiti teachers' willingness to teach social studies online after the CORONA pandemic?

3- Are there any significant differences, referred to gender, among Kuwaiti teachers' willingness to teach social studies online after the CORONA pandemic?

\section{Research hypothesis}

follows:

Based on the study's $3^{\text {rd }}$ question, we state the research hypothesis as

There will be no significant differences between male and female Kuwaiti teachers' willingness to teach social studies online after the CORONA pandemic.

\section{Literature Review}

Smart classrooms are technology-based learning that is proposedly increasing students' capabilities. It makes the education system more attractive and interactive (Phoong, Phoong, Moghawemi, \& Sulaiman, 2019). Online learning utilizes such technologies. This type of learning has become a widespread method for providing education at the graduate and undergraduate levels (Wallace, 2003).

According to Sharma \& Parmar (2017), up to the early years of the $21^{\text {st }}$ century, the researchers' interest in this type of online learning seems to have been very limited (Sharma, \& Parmar, 2017, p. 106). Up to the early beginnings of the $21^{\text {st }}$ century, as Diaz \& Cartnal (1999) reported, "there is not an overabundance of research on distance learning" (Diaz \& Cartnal, 1999, p. 130). Also, there seemed to be a difference in how the term was used from continent to continent and from country to country (Moore, Dickson-Deane, \& Galyen, 2011). Easton (2003), on his part, claims that the teacher's role in online learning is "ambiguous and ill-defined and it requires many skills for 
effective teaching. So, conceptualizing and understanding the social interactions and constructs entailed by online education needed extensive work and literature to provide insights into social aspects of online teaching and learning, such as community development, teachers, and students (Wallace, 2003, p. 1).

Al-Fadhli's (2009) study results also showed that many have misconceptions about e-learning, and very few were aware of the e-learning capabilities. Thus, some researchers called for adopting every necessary measure to improve this form of learning (Khan, Nabi, Khojah, and Tahir, 2021). Alexander, Truell, \& Zhao (2012) invited educators to stress their students' successful online completion requirements. Kimura (2020), on his part, emphasized the importance of close communication between professors and students to ensure that students perform well in the class; he regards it as a significant factor for improving the online learning experience. Alshamrani (2019) noted that we need to equip the students with the required technology entities such as internet connectivity and computers. On their part, (Aliyyah, Rachmadtullah, Samsudin, Syaodih, Nurtanto, \& Tambunan, 2020) have proposed formulating online learning goals aligned with the curriculum, changing the curriculum, and accelerate training on the use of technology applications. In addition, collaboration among teachers, parents, schools must be encouraged. Taylor (2002) points out that faculty life will become more complicated until members become proficient in online learning (Taylor, 2002, p. 1).

Regardless of these remarks, this learning type seems to be gaining remarkable popularity among some people involved, students, teachers, and parents. It increased faculty and learner access to information (Arkorful \& Abaidoo, 2015, p. 18). However, that was not always the case with others. For example, Hannay \& Newvine's (2006) study results showed that not everyone enjoys being educated through online learning. Dumford \& Miller (2018) allege that it might benefit certain types of engagement while deterring others. It appears to be preferred mainly by older students rather than undergraduates who flourish more in traditional classrooms (Dumford \& Miller, 2018). Xu \& Jaggars' (2013) study supports this claim of suitability to older students who live off-campus. 
In contrast, Hartnett, St. George \& Dron (2011), on the other hand, tie it to the learner's intrinsic motivation and the practitioner's influencing role. Furthermore, Deal (2002) refers to the availability of instructor support as playing such a role in building students' preference for such learning. That led Bernard and Rubacava (2000) to pinpoint the necessity of carefully considering the learner's characteristics and the learning context to enhance students' appreciation of online learning.

\section{Online learning advantages and disadvantages}

Easton (2003) indicates an increased demand for college courses taught over the "World Wide Web." Furthermore, Radović-Marković (2010) predicts that online learning "will soon become the dominant form of education in the world, which is to reach its peak in a few years" (RadovićMarković, 2010, p. 296). That led Kim \& Bonk (2006) to remind the educational institutions of their need to consider whether they are ready to meet growing learner demands in the coming years (Kim \& Bonk, 2006, p. 29). However, De Paepe, Zhu, and Depryck (2018) disagree with this notion and anticipate that online learning's perceived disadvantages might be a factor hindering the transition to this type of learning.

Educators should priorly examine the gains of their intended programs. That includes its cons and pros, which must be considered in their decisions. The available online learning research work reveals that this type of learning encompasses many advantages and disadvantages.

\section{Advantages of online education:}

From the institutions' perspective, the cost advantage comes as one of the primary advantages. Xu \& Jaggars (2013) pinpoint the broader colleges' offerings of additional courses among these online learning advantages. James (2002) refers to the advantage of its distribution inexpensiveness to the colleges. Arkorful \& Abaidoo (2015) and Mirkholikovna (2020) point to its costeffectiveness in the sense of offering learning opportunities to more significant numbers of students with no need for many buildings and with a compensation of academic staff scarcity. Lippart (2020), in his study, pointed that "educators view the potential for online to supplement the learning of geographic skills as high and would be eager to incorporate it into their 
classrooms on a more regular basis if empowered to do so" (Lippart, 2020, p. 46). Al-Fadhli (2009) reported that faculty members in Kuwait University noted four significant e-learning advantages: prompting self-learning, promoting better learning quality, easing the teaching process, and flexibility (Al-Fadhli, 2009).

From the student's perspective, online advantages included the convenience of learning anytime, anywhere without interference with social commitment, and instructor availability whenever needed for additional inputs and explanation (ElMansour \& Mupinga, 2007; Alexander, Truell, and Zhao, 2012; and Xu \& Jaggars, 2013). Arkorful \& Abaidoo (2015), Mirkholikovna (2020), and Hiranrithikorn (2019) refer to this as its flexibility in time, place, and individual differences. They add the advantage of providing for learners' relations through the use of discussion forums. James (2002), Arkorful \& Abaidoo (2015), Alshamrani (2019), and Hiranrithikorn (2019) accredit the advantages of adding quicker learning at the student's pace. James (2002) adds to its accreditation the benefits of collaborative learning and easy update and access. He debates using such terms as extendability, accessibility, and suitability.

In their opinion, Radović-Marković (2010) and Mirkholikovna (2020) suggest that online learning will help students be best suited to their future job position requirements since they acquired the technical skills favored by future job establishments during their online learning. Furthermore, Alexander, Truell, \& Zhao (2012) pinpoint the advantage of not being compelled to deal with disruptive and frequent question-asking students.

Mirkholikovna (2020) adds that a person will not be dependent on transport (Mirkholikovna, 2020). So, saving the cost and time of commuting, traveling, and avoiding traffic jams is another advantage (Hiranrithikorn, 2019). Furthermore, Dung (2020) points to the edges of protecting the health and safety of the individuals and the community and having easy access to online resources. Added to all of that is what Alshamrani (2019) and Khan, Nabi, Khojah, \& Tahir (2021) have reported of the easy access of resources to advantage this type of learning. 


\section{Disadvantages of online education:}

Besides the reported advantages, the research has also shown that online learning was not devoid of disadvantages. These perceived disadvantages might be a factor hindering the transition to online learning (De Paepe, Zhu, and Depryck, 2018, p. 1).

Many researchers pointed to such disadvantages. Arkorful \& Abaidoo (2015), for example, warn that, above all these disadvantages, is that this type of learning might not be suitable for all disciplines other than social sciences and humanities. Mirkholikovna (2020), for example, says that "you cannot learn online to become a pilot or surgeon" (Mirkholikovna, 2020). At the same time, Chu (2014) referred to the "overloading of the working memories caused by the students' eagerness to complete the many learning tasks" as one of these disadvantages that can harm their achievements. Dumford \& Miller (2018) and Arkorful \& Abaidoo (2015) attribute this to less exposure to effective teaching and lower interaction quality than face-to-face learning.

Dung (2020) marked the disadvantage of the extensive string at digital screens as above all other disadvantages reported by $93.6 \%$ of his study participants. Alshamrani (2019) noted the health issues of online learning too. EIMansour and Mupinga (2007) mentioned some disadvantages as feeling "lost in cyberspace" when technical problems occur and the instructor's limitations of knowing the student personally. James (2002), on his part, mentioned the frustrating net bandwidth constraints and limitations. Finally, Erguvan (2014) has reported that his sample of 4 male and four female participant perceptions of program weaknesses included experienced technical problems in addition to grading difficulties. Alexander, Truell, and Zhao (2012) referred to such technology-related disadvantages. He added the disadvantages of other students' cheating, assignment directions misunderstanding, and the instructor's procrastination when not understanding the content. Arkorful \& Abaidoo's (2015) study supports this, which Mirkholikovna (2020) names teachers' lack of constant control and monitoring. Finally, Dung (2020) and Hiranrithikorn (2019) refer to its negative effect and impact on socialization skills.

Some of the research examined the effect of the student gender on their perceptions and attitudes towards online learning. Some of these studies have shown that female students were more than males in their positive 
perceptions. For example, on a total of 420 Ball State University students, Alexander, Truell, and Zhao's (2012) study results have shown that female students were more likely to rate the advantages of online learning more than males. Rovi \& Baker's (2005) study on a sample of 162 female graduate students and 31 male graduate students reached similar results. Female students in this study felt that their online learning experiences were more aligned with their educational values and goals. The results have also shown that females learned more than their male peers. That was not the case in Yukselturk and Bulut's (2009) study, in which the participants were 101 male and 44 female students in the Turkish Middle East Technical University in Ankara. This study did not find statistically significant mean differences among motivational beliefs, self-regulated learning variables, and achievement related to students' gender. Alrasheedi's (2009) study results showed that male teachers had more positive attitudes than female teachers toward (ICT) education. However, there was no significant difference between male and female teachers on attitudes and ICT use combined dependent variables. Khany \& Ghoreyshi (2013) claim that the effect of teachers' demographical variables such as age and gender "seems not to have a clear picture" (Khany \& Ghoreyshi 2013, p. 613). Eslaminejad, Masood, \& Ngah (2010), in their study, indicated that they did not find any significant correlation between the variable of gender and instructors' readiness for e-learning (Eslaminejad, Masood, \& Ngah's, 2010, p. 409).

Sulaiman \& Dashti's (2018) research concerned itself with studying the effect of student gender on their perceptions of "SmartPhone" learning. The researchers conducted this study on a sample of 1200 university undergraduate students. It has revealed that female students were more satisfied than males, public universities' students were more satisfied than private universities' students, and Kuwaitis more than non-Kuwaitis with Smartphone learning. Alshamrani (2019) also reported that female students showed positive attitudes toward the e-learning environment. The researcher claims that online learning ensures that shy students, specifically females, would not suffer from this trait when learning online. Kuwait's society is one of the many conservative societies in the Arabian Gulf region. Thus, most of the research on online learning has shown the females favoring this learning to exceed males. Cultural and social values in Middle Eastern countries are usually 
based on gender segregation, which interprets why females are more positive in evaluating e-learning (Alshamrani, 2019, p. 18).

Several studies have examined the perceptions and willingness of teachers and faculty members to teach online. Bolliger\& Wasilik (2009) assert that "the success of online programs rests on the commitment of the faculty and their Willingness to continue the development and delivery of online courses" (Bolliger\& Wasilik, 2009, p. 114). Ouma, Awuor, \& Kyambo (2013) indicated that teachers are willing and ready to teach through computers. Zhu, Valcke, \& Schellens (2010) investigated the teachers' willingness to adopt online learning. They found that teachers who expressed a need or interest in innovation and willingness to learn and are familiar with internet technologies are more willing to adopt e-learning and an online collaborative approach. Institutional incentives and relevant technical training are also necessary for elearning adoption (Zhu, Valcke, \& Schellens, 2010, p. 159). The result of AlFadhli's (2009) study on a sample of 118 Kuwait University faculty members from various colleges supports this notion, and they have shown a strong correlation between the level of computer competency and faculty acceptance of e-learning. However, faculty members in this study have shown a reluctance/phobia to embrace technology and preferred other learning modes than e-learning (Al-Fadhli's, 2009, p. 227). Kreijns, Vermeulen, Kirschner, Buuren, \& Acker (2013) stated that "teachers are reluctant to use (ICT), that is, Information \& Communication Technologies." They added that this "may be due to negative attitudes toward the ICT" and suggest intervening to change these attitudes (Kreijns, Vermeulen, Kirschner, Buuren, \& Acker, 2013, p. 13).

Tsai \& Chai (2012) signaled three barriers for teachers' willingness to technology integration in education. They named lack of adequate access, time, training, institutional support as first-order barriers; teachers' pedagogical beliefs, technology beliefs, teachers' willingness to change as the second-order barriers; and the lack of design thinking skills and disposition as the third-order barriers barrier for technology integration. The researchers claimed that teachers could actively and fluently undertake technology integration by reducing the third-order barrier (Tsai \& Chai, 2012, p. 1059). Kundu (2018) has also investigated 175 Indian West Bengal primary and secondary teachers' willingness to adopt online teaching. He concluded that "two critical factors, teacher's roles, and teacher competency, should be attended to" and pointed 
to its positive relation to such teacher's Willingness (Kundu, 2018, p. 49). Haydn \& Barton (2008) discussed their study's participants' factors they felt were either conducive or unhelpful to developing ICT use in the department. Choosing a teacher's own "agenda and control over work" was the sole positive factor found. Lack of time to plan and execute, difficulty securing access to computer suites, and the limited availability of data projectors in 'ordinary' classrooms that would allow for ICT use were some of these negative factors mentioned by the participating teachers in this study (Haydn \& Barton, 2008, p. 442). Alrasheedi's (2009) study results showed that teachers with ICT training showed more positive attitudes than those with no ICT training. AlHunaiyyan, Alhajri, \& Al-Sharhan (2017) have also found in their study on 132 instructors from different higher education institutions in Kuwait that instructors have moderately positive opinions about e-learning among females. Al-Hunaiyyan, Alhajri, \& Al-Sharhan's (2018) study on 623 students and 132 instructors confirmed that result. The study also indicated that instructors and students are very familiar with mobile devices and their applications.

However, research on online learning in Kuwait's educational institutions, compared to other countries' institutions, is limited, but some such research is worth noting and referring to its findings. Of these is Almisad's (2015) study. This study brought the higher education practitioner's attention to the need for enhancing technology adoption in education. It involved a sample of 160 Engineering class students and 17 English language students, and the results indicated that the students have positive perceptions of that educational tool's usefulness. Al-Fadhli (2008), on a sample of 45 students, found that students felt that the use of the learning management system (LMS) and other communication technology reduced the cultural and social limitations imposed by the conservative Kuwaiti society. That was explicitly true in females who could collaborate with the educator and other peers outside campus hours, which would not have been possible without this technology. In Al-Othman's (2004) study, students majoring in English at the College of Education in Kuwait University indicated that the online course's use had helped them gain new skills compared to the traditional classroom setting. In that study, males have significantly differed from females on the achievement test. 
This literature review has shown that several factors seem to have played some role in these conflicting perceptions. These factors are mostly related to the way the concerned parties perceive the online teaching advantages and disadvantages. Since online teaching has some advantages and disadvantages, it might be natural to cause different teachers' views, perceptions, and willingness towards its implementation.

In conclusion, teachers' willingness to do online teaching seems to differ according to different perceptions of teachers. Some teachers appear to be reluctant to use this internet technology-based type of education. In contrast, others show high enthusiasm to revert to it and completely switch from the traditional face-to-face classrooms. According to Almisad's (2015) study, research on online learning in Kuwait's educational institutions is limited (Almisad, 2015, p. 17). That includes research on Kuwaiti teachers' willingness to teach online using the internet. Therefore, research on Kuwaiti teachers' willingness to online teaching must be of Kuwaiti researchers' imperative priorities.

\section{Research Methodology \\ Study Design}

The present study's focus was based on the review of the previous studies to determine the most suitable study design and procedures for developing the data collection instrument. The research used a quantitative descriptive design to allow the researcher to obtain and examine data and describe the willingness of the Kuwaiti teachers to teach social studies online after the CORONA pandemic. These data, then, were collected online through a questionnaire developed by the present researcher and obtained from a sample of social studies teachers. Data analysis was then carried out to help in the research's discussion section.

\section{Participants}

The study sample consisted of 283 social studies teachers of different gender who were willing to respond to its instrument. Two hundred thirty participants were female teachers (81.3\%), and 53 were males (see Table 1 ). 
Table 1

The study sample according to the gender variable.

\begin{tabular}{|c|c|c|}
\hline Sample Gender & N & Percentage \\
\hline Males & 53 & $18.7 \%$ \\
\hline Females & 230 & $81.3 \%$ \\
\hline Total & 283 & $100 \%$ \\
\hline
\end{tabular}

\section{Data Collection}

The data collection procedure involved implementing a researcherdesigned questionnaire, which consisted of 37 items. The researcher developed it after reviewing previous studies first. Secondly, its construct validity was obtained after presenting the questionnaire to 5 colleagues. Thirdly, their observations that included deleting, adding, and modifying the instrument were used to put it in its final form. (See table 2).

Table 2

Description of the study instrument

\begin{tabular}{|c|c|}
\hline Willingness Factors & Number of Items \\
\hline Teacher Related Factors & 9 \\
\hline Class Activities Factors & 6 \\
\hline Learning Environment Factors & 8 \\
\hline Student Behaviors Factors & 6 \\
\hline Student Characteristics Factors & 7 \\
\hline Total & $\mathbf{3 7}$ \\
\hline
\end{tabular}

A five-point Likert scale, Highly Agree (5), Agree (4), Moderately Agree (3), Disagree (2), and Strongly Disagree (1), was used to calculate the study sample's responses on the study instrument. Table 3 shows the level of verification intervals for each response in the five-point Likert scale.

Table 3

Verification intervals for each of the five responses

\begin{tabular}{|c|c|c|c|}
\hline Likert Scale & Interval & Difference & Description \\
\hline 1 & $1.00-1.79$ & .79 & Strongly Disagree \\
\hline 2 & $1.80-2.59$ & .79 & Disagree \\
\hline 3 & $2.60-3.39$ & .79 & Moderately Agree \\
\hline 4 & $3.40-4.19$ & .79 & Agree \\
\hline 5 & $4.20-5.00$ & .80 & Strongly Agree \\
\hline \multicolumn{4}{|r|r}{ r } \\
\hline
\end{tabular}




\section{Reliability of the instrument}

The researcher calculated the Cronbach alpha coefficient to ensure the reliability of the study instrument. As a result, the reliability coefficient on each of the study factor domains is high. Furthermore, the general reliability score of (0.98) was very high, thus, indicating the reliability of results reached by the study (see table 4).

Table 4

Alpha Cronbach reliability coefficients of the study instrument.

\begin{tabular}{|c|c|c|c|}
\hline$\#$ & Factor Domain & Number of Items & Alpha \\
\hline 1 & Teacher Related Factors & 9 & .92 \\
\hline 2 & Classroom Activities Factors & 6 & .92 \\
\hline 3 & Learning Environment Factors & 8 & .95 \\
\hline 4 & Student Behaviors Factors & 6 & .91 \\
\hline 5 & Student Characteristic Factors & 7 & .94 \\
\hline \multicolumn{2}{r|}{ Total } & $\mathbf{3 7}$ & .98 \\
\hline
\end{tabular}

\section{Data Analysis}

To analyze the data collected from the study sample, the researcher used the following statistical methods:

1- Calculate the Pearson correlation coefficient to ensure the validity of the study instrument.

2- Calculate the Alpha Cronbach to ensure the stability of the study instrument.

3- Calculate the means and the SD of the responses of the study to the questionnaire statements.

4- Calculate T-test values of the differences between the responses of the study sample according to the gender variable (malefemale).

We calculated the Pearson correlation coefficient to measure the coefficient correlations between the scores on each factor domain in the study and the general score to ensure the coherence and homogeneity between these domains. As a result, the correlation coefficients between all the questionnaire factor domains and the questionnaire's total score are statistically significant (1\%), indicating a high internal consistency validity (see table 5). 
Table 5

Pearson correlation coefficient for the validity of the study instrument

\begin{tabular}{|c|c|c|c|c|c|c|}
\hline Domain & $\mathbf{1}^{\text {st }}$ & $\mathbf{2}^{\text {nd }}$ & $\mathbf{3}^{\text {rd }}$ & $\mathbf{4}^{\text {th }}$ & $\mathbf{5}^{\text {th }}$ & Total \\
\hline $\mathbf{1}^{\text {st }}$ & 1 & $.883^{* *}$ & $.833^{* *}$ & $.808^{* *}$ & $.826^{* *}$ & $.931^{* *}$ \\
\hline $\mathbf{2}^{\text {nd }}$ & $.883^{* *}$ & 1 & $.854^{* *}$ & $.844^{* *}$ & $.843^{* *}$ & $.940^{* *}$ \\
\hline $\mathbf{3}^{\text {rd }}$ & $.833^{* *}$ & $.854^{* *}$ & 1 & $.896^{* *}$ & $.866^{* *}$ & $.949^{* *}$ \\
\hline $\mathbf{4}^{\text {th }}$ & $.808^{* *}$ & $.844^{* *}$ & $.896^{* *}$ & 1 & $.844^{* *}$ & $.932^{* *}$ \\
\hline $\mathbf{5}^{\text {th }}$ & $.826^{* *}$ & $.843^{* *}$ & $.866^{* *}$ & $.844^{* *}$ & 1 & $.935^{* *}$ \\
\hline Total & $.931^{* *}$ & $.940^{* *}$ & $.949^{* *}$ & $.932^{* *}$ & $.935^{* *}$ & 1 \\
\hline
\end{tabular}

$(* *)$ Correlation is significant at 0.01 level

\section{Study Results}

Following, we present the results of the data analysis related to the study's three main questions alternatively.

\section{Question 1}

This question stated: What is Kuwaiti teachers' willingness to teach social studies online after the CORONA pandemic?

This question addressed whether the Kuwaiti teachers will be willing to teach social studies online after the lapsing of the Corona pandemic. Accordingly, the sample of the Kuwaiti social studies teachers was asked whether they are "unwilling to future teach social studies after the CORONA pandemic online," and the results of their responses are represented in the following table 6 .

Table 6 shows that $25 \%$ of the sample strongly disagreed with this statement, $7.8 \%$ disagreed, $18.7 \%$ moderately agreed, $8.1 \%$ agreed, and $39.9 \%$ strongly agreed. It also shows that the mean of the sample's social studies teachers' response scored 3.29 with an SD of 1.642. Thus, the mean score and SD indicate that the Kuwaiti social studies teachers' willingness to continue online teaching came with a moderate agreement.

Nevertheless, the results also indicate that the number of unwilling teachers is not that meager. Those unwilling teachers were totaling around $33.2 \%$ of the respondents. Thus, they indicate many unwilling teachers, which can carry adverse effects on the educational process. Therefore, this matter needs to be appropriated very carefully. 
Table 6

Sample's response percentage; and means and SD on $1^{\text {st }}$ question.

I am unwilling to future teach social studies after the CORONA pandemic online.

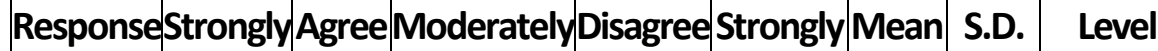

\begin{tabular}{|c|c|c|c|c|c|c|c|c|}
\hline הונדת & Agros & 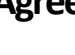 & Areo & 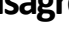 & Dicagreo & 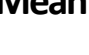 & 0.6. & encis \\
\hline $\mathrm{N}$ & 72 & 22 & 53 & 23 & 113 & & & \\
\hline$\%$ & $25.4 \%$ & 7.8 & 18.7 & 8.1 & 39.9 & 3.29 & 1.64 & Modera \\
\hline
\end{tabular}

\section{Question 2}

This question stated: "What factors affect Kuwaiti teachers' willingness to teach social studies online after the CORONA pandemic"?

This question addresses the various factors that affect the willingness of Kuwaiti teachers to future teaching of the social studies post to the Corona pandemic ordeal.

We first begin by showing the results in which we compare the general means of each factor domain to present the most causing teachers' unwillingness; then, we will show the results on each domain statements' means.

\section{First: Results related to a comparison of the study domains' means}

These factors are presented in different domains, and each domain pertains to one of the following factors:

1- teacher-related factors ( $1^{\text {st }}$ domain),

2- classroom activities factors ( $2^{\text {nd }}$ domain),

3- learning environment factors ( $3^{\text {rd }}$ domain),

4- student behaviors factors ( $4^{\text {th }}$ domain), and

5- student characteristic factors ( $5^{\text {th }}$ domain).

Table 7 shows these five domains in terms of their ranking in affecting the teachers' unwillingness to teach online in the future after the Pandemic. 
Table 7

Domains' rankings in affecting teachers' unwillingness.

\begin{tabular}{|c|c|c|c|c|}
\hline$\#$ & Factor Domain & Means & SD & Ranking \\
\hline 1 & Teacher-related factors. & 2.87 & 1.163 & 5 \\
\hline 2 & Classroom activities factors. & 2.90 & 1.261 & 4 \\
\hline 3 & Learning environment factors. & 3.42 & 1.220 & 1 \\
\hline 4 & Student behaviors factors. & 3.29 & 1.218 & 2 \\
\hline 5 & $\begin{array}{c}\text { Student characteristics } \\
\text { factors. }\end{array}$ & 3.19 & 1.256 & 3 \\
\hline \multicolumn{2}{|c|}{} & $\mathbf{3 . 1 4}$ & \multicolumn{2}{|c|}{$\mathbf{1 . 0 8 6}$} \\
\hline
\end{tabular}

The general mean of 3.14 (SD 1.86) indicates moderate agreement among the sample teachers that these factors are causing them not to be willing to sustain online teaching after the Pandemic.

Taking each group or domain of these factors separately, the domain of the learning environment factors appears to be the most negatively affecting the teachers' willingness to continue teaching online in the future. It ranked first among the other factors' domains with a mean of 3.42 and SD of 1.220, indicating the teachers' "agreement" that the learning environment causes that unwillingness. That might indicate that the Kuwaiti social studies teachers do not consider that online teaching could compensate for the face-to-face assets.

The sample teachers showed moderate agreement on the other domains.

The student behaviors domain ranked $2^{\text {nd }}$ with a mean of 3.29 and SD of 1 . 218. That is probably because the online teacher's control of students' behaviors can be fragile and cannot, by any means, emulate that of the faceto-face teacher's control of such behaviors. They seem to have sensed that some students could misbehave without being identified during the Corona imposed online teaching. Students' characteristics domain ranked $3^{\text {rd }}$ with a mean of 3.19 and SD of 1.256, indicating that the respondents view these characteristics do not affect the students' learning, implying no relation between online learning and these characteristics. The classroom activities domain ranked $4^{\text {th }}$ with a mean of 2.90 and SD of 1.261 . These results also 
imply that classroom activities will not be affected by the type of learning and could be equally carried out in both online and face-to-face types.

However, this table also shows that the domain of teacher-related factors domain ranked last in negatively affecting teachers' willingness to continue teaching online in the future with a mean of 2.87 and SD of 1.163. That connotes those social studies teachers have high confidence in their teaching skills. That made them consider the teacher-related factors the least significant cause of their willingness or unwillingness to teach online, as do the other factors.

\section{Second: Results on each domain statements' means}

The following is a presentation of the results related to the means of each domain's statements.

\section{1-Results pertinent to the "teacher-related factors" domain}

This section shows the means and SD of the sample's responses on each statement included in the teacher-related factors domain. The social studies teachers think would negatively affect their willingness to future online teaching.

Table (8) shows the total mean of the social studies teachers' responses in the teacher-related factors domain. It also shows the mean and SD of their responses to the statements in this domain.

Table 8

Means and SD of sample's responses on the $1^{\text {st }}$ domain statements.

\begin{tabular}{|c|l|c|c|c|}
\hline$\#$ & \multicolumn{1}{|c|}{ Statement } & Mean & S.D. & Rank \\
\hline 1 & $\begin{array}{l}\text { Reflected feelings of talking to devices rather than } \\
\text { students on my conduct. }\end{array}$ & 2.95 & 1.550 & 5 \\
\hline 2 & Impedes teacher's creativity of stimulating teaching. & 2.80 & 1.592 & 6 \\
\hline 3 & Inability to sense actual students' reactions. & 3.82 & 1.350 & 1 \\
\hline 4 & The health hazards accompanying lengthy sitting. & 3.25 & 1.531 & 2 \\
\hline 5 & The pressurizing stress of online teaching. & 3.05 & 1.539 & 4 \\
\hline 6 & The joylessness of online teaching. & 3.07 & 1.634 & 3 \\
\hline 7 & Lessened professional promotion opportunities. & 2.69 & 1.533 & 7 \\
\hline 8 & The unpreparedness in the pre-service institution. & 2.41 & 1.469 & 8 \\
\hline 9 & $\begin{array}{l}\text { I am utterly ignorant of the use of the internet and } \\
\text { devices. }\end{array}$ & 1.82 & 1.300 & 9 \\
\hline \multicolumn{2}{|c|}{ Total } & $\mathbf{2 . 8 7}$ & $\mathbf{1 . 1 6 3}$ & \\
\hline
\end{tabular}


The total mean of this domain is (2.87) with an SD of (1.163), which indicates that the sample teachers showed agreement that their willingness to future online teaching is affected by teacher-related factors, which might hinder such willingness.

This domain consisted of nine items. The means ranged between (3.82) with a degree of agreement and (1.82) with a degree of disagreement. The SD ranged between (1.350) and (1.300).

The Inability to sense actual students' reactions ranked $1^{\text {st }}$ in sequence ahead of the other factors in this domain with a mean of (3.82). That shows the teachers' unwillingness to teach online after the Pandemic elapses might be affected by this factor. The least in the ranking of these factors that the teachers did not consider would affect their willingness was to be utterly ignorant of the use of the internet and devices. We live in a technology literacy era in which everyone is familiar with computers and the internet. It becomes no wonder that this factor was last in the rank order.

\section{2-Results pertinent to the "classroom activities factors" domain}

This section shows the means and SD of the sample's responses on each statement in the classroom activities factors domain. The social studies teachers think would negatively affect their willingness to future online teaching.

Table (9) shows that the total mean of the social studies teachers' response in the classroom activities factors domain was (2.90) with an SD of (1.261). That indicates that teachers moderately agree that the factors in this domain would affect their willingness to teach in the future using online teaching. It also shows the mean and SD of their responses to the statements in this domain.

Table 9

Means and SD of sample's responses on the $2^{\text {nd }}$ domain statements.

\begin{tabular}{|c|c|c|c|c|}
\hline$\#$ & Statement & Mean & SD. & Rank \\
\hline 1 & Does not suit teaching social studies. & 2.45 & 1.475 & 6 \\
\hline 2 & Narrowed chances of student collaboration. & 3.39 & 1.460 & 1 \\
\hline 3 & Ineffective student interaction with their teacher. & 3.22 & 1.433 & 3 \\
\hline 4 & Uneasy communication with the students. & 3.24 & 1.479 & 2 \\
\hline 5 & Class activities cause student fatigue. & 2.49 & 1 & 5 \\
\hline 6 & The difficulty in the provision of diversified learning resources. & 2.59 & 514 & 4 \\
\hline & Total & $\mathbf{2 . 9 0}$ & $\mathbf{1 . 2 6 1}$ & \\
\hline
\end{tabular}


This domain consisted of six items. The means ranged between (3.39) with a degree of moderate agreement and (2.45) with a degree of disagreement. The SD ranged between (1.460) and (1.475).

The Narrowed chances of student collaboration ranked $1^{\text {st }}$ in sequence ahead of the other factors in this domain, and the least in the ranking was the item stating, "Does not suit teaching social studies." The results indicate that teachers disagree on the unsuitability of the online teaching of social studies, but at the same time note a major defect related to its provision of students' collaboration. The students feel apart in online teaching, which might have caused the teachers to consider it a significant defect.

\section{3-Results pertinent to the "learning environment factors" domain}

This section shows the means and SD of the sample's responses on each statement included in the learning environment factors domain. The social studies teachers think would negatively affect their willingness to future online teaching.

Table (10) shows that the social studies teachers' total mean in the learning environment-related factors domain was (3.42) and an SD of 1.220, indicating that they agree that these factors retard their willingness to future online teaching. It also shows the mean and SD of their responses to the statements in this domain.

Table 10

Means and SD of sample's responses on the $3^{\text {rd }}$ domain statements.

\begin{tabular}{|c|c|c|c|c|}
\hline$\#$ & Statement & Mean & S.D. & Rank \\
\hline 1 & Inappropriateness of the learning environment at home. & 2.97 & 1.496 & 8 \\
\hline 2 & The probability of Wi-Fi or device interruption \\
& $\begin{array}{c}\text { occurrences. } \\
3\end{array}$ & 3.81 & 1.278 & 1 \\
\hline 4 & Steady sitting side effects on the student's health. & 3.25 & 1.458 & 6 \\
\hline 5 & $\begin{array}{c}\text { The concomitant students' feelings of insecurity and } \\
\text { discomfort. }\end{array}$ & 3.02 & 1.491 & 7 \\
\hline 6 & The rareness of student cooperation opportunities. & 3.37 & 1.437 & 5 \\
\hline 7 & The lack of direct contact with teachers \& other students. & 3.61 & 1.377 & 4 \\
\hline 8 & Negligence and oversight of student's emotions. & 3.64 & 1.406 & 3 \\
\hline & Total & $\mathbf{3 . 4 2}$ & $\mathbf{1 . 2 2 0}$ & \\
\hline
\end{tabular}


The learning environment factors domain consisted of eight statement items, and their means ranged between (3.81) with an agreement degree and (2.97) with a degree of moderate agreement. The SD ranged between (1.278) and (1.496).

Statement 2, "The probability of Wi-Fi or device interruption occurrences," ranked in the $1^{\text {st }}$ ranking, whereas statement 1, "Inappropriateness of the learning environment at home," ranked last in the array as causing teachers' unwillingness to online teaching. That might be because many teachers have experienced such interruption occurrences amidst their online teaching during the Pandemic, which might have led the teachers to give it this uppermost rank amongst other statements of this domain.

\section{4- Results pertinent to the "student behavior factors" domain}

This section shows the means and SD of the sample's responses on each statement in the student behavior factors domain. The social studies teachers think would negatively affect their willingness to future online teaching.

Table (11) shows that the social studies teachers' total mean in the student behavior factors domain was (3.29) and an SD of 1.218, indicating that they moderately agree that these factors retard their willingness to future online teaching. It also shows the mean and SD of their responses to the statements in this domain.

Table 11

Means and SD of sample's responses on the 4th domain statements.

\begin{tabular}{|c|c|c|c|c|}
\hline$\#$ & Statement & Mean & SD & Rank \\
\hline 1 & The hardness of controlling students' chaotic behaviors. & 2.96 & 1.475 & 5 \\
\hline 2 & $\begin{array}{l}\text { The hardness of controlling students' cheating during the } \\
\text { examinations. }\end{array}$ & 3.96 & 1.274 & 1 \\
\hline 3 & The firmness of students' class attendance verification. & 3.29 & 1.544 & 4 \\
\hline 4 & $\begin{array}{l}\text { The hardness of controlling students' deliberate class } \\
\text { time-wasting. }\end{array}$ & 2.62 & 1.528 & 6 \\
\hline 5 & Students' boredom and fatigue sensibilities. & 3.33 & 1.488 & 3 \\
\hline 6 & $\begin{array}{l}\text { The maintenance difficulty of students' attention to the } \\
\text { class teacher. }\end{array}$ & 3.61 & 1.406 & 2 \\
\hline \multicolumn{2}{|r|}{ Total } & 3.29 & 1.218 & \\
\hline
\end{tabular}


The student behavior factors domain consisted of six statement items, and their means ranged between (3.96) with an agreement degree and (2.62) with a moderate degree of agreement. The SD ranged between (1.278) and (1.496). Ranking first was statement 2, "The hardness of controlling students' cheating during the examinations." Last in the ranking was statement 6, The hardness of controlling students' deliberate class time-wasting." The results indicate that the teachers' unwillingness to continue future online teaching might have been based on what they have experienced of the frustrating difficulties in keeping an eye on students' cheating-free examination performances.

\section{5- Results pertinent to the "student characteristics factors" domain}

This section shows the means and SD of the sample's responses on each statement included in the student characteristics factors domain. The social studies teachers think would negatively affect their willingness to future online teaching.

Table (12) shows that the social studies teachers' total mean in the student characteristics factors domain was (3.19) and an SD of 1.256. Thus, they indicated that they moderately agree that these factors retard their willingness to future online teaching. It also shows the mean and SD of their responses to the statements in this domain.

Table 12

Means and SD of sample's responses on the 5th domain statements.

\begin{tabular}{|l|l|l|l|l|}
\hline$\#$ & Statement & Mean & SD & Rank \\
\hline 1 & Inappropriate to shy students. & 2.79 & 1.472 & 7 \\
\hline 2 & Inappropriate to students with learning difficulties. & 3.52 & 1.400 & 1 \\
\hline 3 & It is not attractive to every student. & 3.28 & 1.387 & 3 \\
\hline 4 & Does not suit the learning abilities of all students. & 3.49 & 1.408 & 2 \\
\hline 5 & Lessens some students' self-confidence. & 3.11 & 1.472 & 5 \\
\hline 6 & Causes tensions of some students. & 3.02 & 1.524 & 6 \\
\hline 7 & $\begin{array}{l}\text { Weakens some students' incentives and } \\
\text { eagerness. }\end{array}$ & 3.14 & 1.527 & 4 \\
\hline Total & $\mathbf{3 . 1 9}$ & $\mathbf{1 . 2 5 6}$ & \\
\hline
\end{tabular}

Table 12 presents the means and SD of each statement in the student characteristics domain. Regarding the teachers' willingness in this domain, 
statement2, "Inappropriate to students with learning difficulties.," ranked $1^{\text {st }}$, and statement1, which stated "Inappropriate to shy students," ranked last in order. That can show that teachers might not be willing to teach online in the future mainly because it does not meet the needs of the learning difficulties of some students, which they might have noticed during their online teaching amidst the Pandemic which derived every school on the globe to resort to online teaching. However, the student shyness does not seem to be causing teachers' refusal or future online teaching.

\section{Question 3}

This question stated: Are there any significant differences, referred to gender, among Kuwaiti teachers' willingness to teach social studies online after the corona Pandemic?

The results related to this question support and confirm its hypothesis. As shown in table 13, it appears that there are no significant differences at any level between the means of male teachers and females on any of the domains of the present study (see table 13). Furthermore, the t value for the difference between the total mean on all study domains of the male teachers (mean 3.15) and female teachers (mean 3.13) was 0.107, which is not significant at any statistical level.

Table 13

$T$ values for differences between the means of male and female teachers.

\begin{tabular}{|c|c|c|c|c|c|c|}
\hline Domain & Gender & $\mathbf{N}$ & Mean & SD & T Value & Sig. \\
\hline \multirow{2}{*}{$\begin{array}{c}\text { Unwillingness to } \\
\text { teach }\end{array}$} & Male & 53 & 3.13 & 1.630 & \multirow[t]{2}{*}{-0.792} & \multirow[t]{2}{*}{0.43} \\
\hline & Female & 230 & 3.33 & 1.647 & & \\
\hline \multirow[t]{2}{*}{ Teacher-related } & Male & 53 & 2.91 & 1.162 & \multirow[t]{2}{*}{0.245} & \multirow[t]{2}{*}{0.81} \\
\hline & Female & 230 & 2.86 & 1.165 & & \\
\hline \multirow{2}{*}{$\begin{array}{c}\text { Classroom } \\
\text { activities }\end{array}$} & Male & 53 & 2.87 & 1.209 & \multirow[t]{2}{*}{-0.142} & \multirow[t]{2}{*}{0.89} \\
\hline & Female & 230 & 2.90 & 1.275 & & \\
\hline \multirow{2}{*}{$\begin{array}{c}\text { Learning } \\
\text { Environment }\end{array}$} & Male & 53 & 3.45 & 0.995 & \multirow[t]{2}{*}{0.169} & \multirow[t]{2}{*}{0.87} \\
\hline & Female & 230 & 3.42 & 1.268 & & \\
\hline \multirow{2}{*}{$\begin{array}{c}\text { Student } \\
\text { behaviors }\end{array}$} & Male & 53 & 3.25 & 1.173 & \multirow[t]{2}{*}{-0.284} & \multirow[t]{2}{*}{0.78} \\
\hline & Female & 230 & 3.30 & 1.231 & & \\
\hline \multirow{2}{*}{$\begin{array}{c}\text { Student } \\
\text { Characteristics }\end{array}$} & Male & 53 & 3.27 & 1.121 & \multirow[t]{2}{*}{0.516} & \multirow[t]{2}{*}{0.61} \\
\hline & Female & 230 & 3.17 & 1.287 & & \\
\hline \multirow[b]{2}{*}{ Total } & Male & 53 & 3.15 & 1.006 & \multirow[b]{2}{*}{0.107} & \multirow[b]{2}{*}{0.91} \\
\hline & Female & 230 & 3.13 & 1.105 & & \\
\hline
\end{tabular}


The scored $t$ - value was -0.792 , indicating no effect of the sex variable of the teachers and that both male and female teachers show similar moderate agreement on this item. From that table, it appears that there is no significant difference between the mean of male (3.13) and female (3.30) Kuwaiti social studies teachers' willingness to continue online teaching in the future. That applies to the differences between the male and female teachers in all other domains.

The analysis of the data also shows no differences, based on the gender variable, between the means of the male teachers (2.91) and female teachers (2.86) in the teacher-related factor domain, between the means of the male teachers (2.87) and female teachers (2.90) in the classroom activitiesrelated factor domain, between the means of the male teachers (3.45) and female teachers (3.42) in the learning environment-related factor domain, between the means of the male teachers (3.25) and female teachers (3.30) in the student behavior-related factor domain, or between the means of the male teachers (3.27) and female teachers (3.17) in the student characteristicsrelated factor domain.

\section{Discussion of the study results}

The present study investigated whether Kuwaiti social studies teachers would be willing to continue online teaching after the Corona Pandemic elapses.

The study has come with some thought-provoking results worth considering by the educational decision-makers. These results are related to whether they should endorse, partially or entirely, online teaching to educate the students or keep up with the formal type of face-to-face schooling. These decisions should be based on the study findings related to social studies teachers' willingness to teach online, with which the present study was concerned. The findings of the study answered its posed questions throughout the present research work.

The first question aimed to examine teachers' willingness, or unwillingness, to teach social studies online after the Corona Pandemic. These findings have clearly shown that teachers are not firmly willing to teach online and that $32.2 \%$ of them were firmly unwilling to do so. Such unwillingness means that many teachers will not perform according to online teaching requirements and may harm the students' achievements. Since the end of this 
Corona Pandemic crisis is not yet clearcut and might continue longer, it becomes necessary to supply the needed grounds to guarantee to lift the interest and willingness in online teaching in every teacher. Hence, we need to provide all teachers, specifically those who showed their unwillingness, with all the necessary means of alleviating their willingness. That can be in the form of training workshops for those illiterate with the new technologies and their needed skills to deal with them. It can also be in the form of specialized sessions for mitigating their suffering. Needless to say, that similar attention is needed for the preparation programs of student-teachers. These programs should consider such issues as well.

The findings of such teachers' disapproval and the unwillingness of online teaching coincide with the results of some other research. This body of research has pointed to some disadvantages that hinder such willingness. Of these are the studies of Chu (2014), Arkorful \& Abaidoo (2015), De Paepe, Zhu, and Depryck (2018), Dumford \& Miller (2018), Alshamrani (2019), Mirkholikovna (2020), and Dung (2020).

On the other hand, the present study results did not support many other studies' findings in which teachers identified many advantages, specifically to the learners. For example, the Ouma, Awuor, \& Kyambo (2013) study indicated that teachers are willing and ready to teach using computers. Other studies including the work of James (2002), ElMansour \& Mupinga (2007), Alexander, Truell, and Zhao (2012), and Xu \& Jaggars (2013), Arkorful \& Abaidoo (2015), Alshamrani (2019), Hiranrithikorn (2019), Mirkholikovna (2020), Dung (2020), and Nabi, Khojah, \& Tahir (2021) reached the same conclusions which contradicted our findings.

That result also contradicted the findings of Chen (2012), in which web-based learning had the highest value in the perception of sample teachers. It also does not come in line with Lippart's (2020) findings, who pointed that the educators would be eager to incorporate it into their classrooms on a more regular basis. Al-Fadhli's (2009) study reached the same conclusion and indicated that college faculty members noted four significant advantages of online learning.

Regarding the study results related to its second question of the factors affecting teachers' willingness to continue teaching online, these results have shown that the factors related to the learning environment domain were 
perceived as the most influential ones, and they preceded all other factors included in the other domains. That results mean that we must make every effort to improve the quality of the learning environment since the teachers showed their disapproval of it. That requires filing its shortages to create the most supportive environment that can win those teachers' satisfaction. That can be achieved by several means. First, families must be alarmed about the necessity of the provision of the proper spaces at home. Second, the needy students must be aided with the requirements of the suitable devices and WIFi service. Finally, internet companies must improve their services to their best to avoid coverage loss.

Our results are supported by Bernard and Rubacava (2000) when they warn against the unsuitability of the "learning context" and advice educators for the necessity of the careful consideration of its suitability to students' characteristics. They are also supported by James (2002); Mupinga (2007); Tsai and Chai (2012); Alexander, Truell, and Zho; Erguvan (2014); and Alshamrani (2019). These studies have pinpointed the learning environment's unsuitability, especially about "being lost in cyberspace" and "net bandwidth constraints."

On the other hand, these results contradict the results of some previous studies. Our results, for example, showed that teachers are not willing to teach online because of the health-related factors involved in the learning environment that retarded that willingness. That was not true in Dung's (2020) study which referred to the advantage of the healthy environment of online learning. Also, our results do support Chen's (2012) statement that Web-based learning can provide teachers and students with a learning environment. However, they also do not support Phoong, Phoong, Moghavvemi, \& Sulaiman (2019) claim that it can provide more "attractive and interactive learning."

The present study investigated the effect of gender on the teachers' willingness to teach online. The results have indicated that there were not any significant differences. Thus, Kuwaiti male and female social studies teachers did not differ in their unwillingness to teach online after the Corona Pandemic crisis. That implies that all teachers, regardless of their gender, look at this issue from the same angle. They all appear to suffer from matters that lead them to such unwillingness. This matter should make the people at stake understand the enormity of teachers' unwillingness which would seriously deter the educational process 
These results are supported by Khany \& Ghoreyshi (2013), whose findings implied that teachers' gender does not exist. They are also supported by Eslaminejad, Masood, \& Ngah, who indicated the same claim. However, on the other hand, these results do not come in line with those of Al-Fadhli (2008); Al-Hunaiyyan, Alhajri, \& Alsharhan (2017); and Al-Hunaiyyan, Alhajri, \& Alsharhan (2017). It was shown, in these studies, that female students and teachers prefer this learning more than males.

\section{Conclusion}

These results have implications for the Kuwaiti educators and decisionmakers to consider for lifting such teachers' willingness to secure their successful use of online teaching leading to fruitful educational gains. Unfortunately, the end of the presence of this globally affecting Coronavirus is not known. It may last for years to come. If teachers' unwillingness continues, that will undoubtedly retard the students' learning process.

The study carries some suggestions and recommendations to meet the case, among these are:

1- We should eliminate the obstacles crippling social studies teachers' willingness to teach through every available online medium.

2- We must concentrate on providing the necessary workshops to alleviate teachers' willingness to its best.

3- More courses are needed in the teachers' preparation institutes to ensure student-teachers internet literacy.

4- More provisions of the needed facilitations must be made, including free devices, Wi-Fi coverages, and other vital facilitations.

5- We suggest conducting future research studies to cover any other aspects that the present study did not attend. 


\section{References}

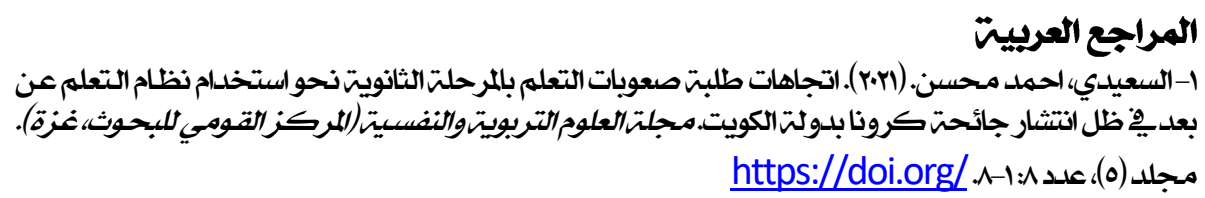

2- Al-Ajmi, N., \& Aljazzaf, Z. (2020). Factors influencing the use of multimedia technologies in teaching English language in Kuwait. International Journal of Emerging Technologies in Learning (IJET), 15(5), 212-234.

3- Alali, W. Q., AlFouzan, W., Aljimi, D., Al-Tawalah, H., Kheirallah, K. A., \& Yimer, G. (2021). Perception and awareness of COVID-19 among health science students and staff of Kuwait University: An online cross-sectional study. medRxiv, https://doi.org/10.1101/2020.12.26.20248891

4- Alexander, M. W., Truell, A. D., \& Zhao, J. J. (2012). Expected advantages and disadvantages of online learning: Perceptions from college students who have not taken online courses. Issues in Information Systems, 13(2), 193-200.

5- Al-Fadhli, S. (2008). Students' Perceptions of E-learning in Arab Society: Kuwait University as a case study. E-Learning and Digital media, 5(4), 418428.

6- Al-Fadhli, S. (2009). Instructor Perceptions of E-learning in an Arab Country: Kuwait University as a case study. E-Learning and Digital Media, 6(2), 221-229.

7- Alhouti, I. (2020). Education during the Pandemic: the case of Kuwait.Journal of Professional Capital and Community. 213-225. https://www.emerald.com/insight/2056-9548.htm

8- Al-Hunaiyyan, A., Alhajri, R., \& Al-Sharhan, S. (2017). Instructors' Age and Gender Differences in the Acceptance of Mobile Learning. International Journal of Interactive Mobile Technologies, 11(4).

9- Al-Hunaiyyan, A., Alhajri, R. A., \& Al-Sharhan, S. (2018). Perceptions and challenges of mobile learning in Kuwait. Journal of King Saud UniversityComputer and Information Sciences, 30(2), 279-289.

10- Aliyyah, R. R., Rachmadtullah, R., Samsudin, A., Syaodih, E., Nurtanto, M., \& Tambunan, A. R. S. (2020). The perceptions of primary school teachers of online learning during the COVID-19 pandemic period: A case study in Indonesia. Journal of Ethnic and Cultural Studies, 7(2), 90-109. 
11- Almisad, B. (2015). A study of students' perceptions and attitudes toward the use of SMS to support learning and teaching at the Kuwait University. (Doctoral Dissertation). The University of WOLLONGONG. https://ro.uow.edu.au/theses.

12- Almisad, B., \& Alsalim, M. (2020). Kuwaiti female university students' acceptance of the integration of smartphones in their learning: an investigation guided by a modified version of the unified theory of acceptance and use of technology (UTAUT). International Journal of Technology Enhanced Learning, 12(1), 1-19.

13- Al-Othman, N. M. A. (2004). The relationship between gender and learning styles in internet-based teaching-a study from Kuwait. Reading, 4(1), 38-54.

14- Alrasheedi, H. S. (2009). Information and communication technology (ICT): Effects of gender and training among Kuwait teachers.

15- Al-Saeedi, A. (2021). Attitudes of students with learning disabilities towards the use of distance learning in the presence of the Coronavirus pandemic in Kuwait. (In Arabic). The Journal of Educational and Psychological Sciences. 5:(8), 1- 8. https://doi.org/ 10.26389/AJSRP.Y230920

16- Alshamrani, M. (2019). An Investigation of the Advantages and Disadvantages of Online Education(Doctoral dissertation, Auckland University of Technology).

17- Arkorful, V., \& Abaidoo, N. (2015). The role of e-learning, advantages, and disadvantages of its adoption in higher education. International Journal of Instructional Technology and Distance Learning, 12(1), 29-42.

18- Bernard, R. M., \& Rubalcava, B. R. D. (2000). Collaborative online distance learning: Issues for future practice and research. Distance education, 21(2), 260-277.

19- Bolliger, D. U., \& Wasilik, O. (2009). Factors influencing faculty satisfaction with online teaching and learning in higher education. Distance education, 30(1), 103-116.

20- Chen, C. A. (2012). Discussion on increasing college teachers' willingness to adopt web-based learning in teaching. Business and Management Research, 1(3), 1-8.

21- Chu, H. C. (2014). Potential negative effects of mobile learning on students' learning achievement and cognitive load-A format assessment perspective. Journal of Educational Technology \& Society, 17(1), 332-344. 
22- Deal, W. F., III (2002). Distance learning: Teaching technology online. Technology and Engineering Teacher, 61(8), 21.

23- De Paepe, L., Zhu, C., \& Depryck, K. (2018). Online Dutch L2 learning in adult education: Educators' and providers' viewpoints on needs, advantages, and disadvantages. Open Learning: The Journal of Open, Distance and eLearning, 33(1), 18-33.

24- Diaz, D. P., \& Cartnal, R. B. (1999). Students' learning styles in two classes: Online distance learning and equivalent on-campus. College teaching, 47(4), 130-135.

25- Dumford, A. D., \& Miller, A. L. (2018). Online learning in higher education: exploring advantages and disadvantages for engagement. Journal of Computing in Higher Education, 30(3), 452-465.

26- Dung, D. T. H. (2020). The advantages and disadvantages of virtual learning. IOSR Journal of Research \& Method in Education, 10(3), 45-48.

267 Easton, S. S. (2003). Clarifying the instructor's role in online distance learning. Communication Education, 52(2), 87-105.

28- El Mansour, B., \& Mupinga, D. M. (2007). Students' positive and negative experiences in hybrid and online classes. College student journal, 41(1), 242.

29- Erguvan, D. (2014). Instructor's Perceptions towards the Use of an Online Instructional Tool in an Academic English Setting in Kuwait. Turkish Online Journal of Educational Technology-TOJET, 13(1), 115-130.

30- Eslaminejad, T., Masood, M., \& Ngah, N. A. (2010). Assessment of instructors' readiness for implementing e-learning in continuing medical education in Iran. Medical teacher, 32(10), e407-e412.

31- Hannay, M., \& Newvine, T. (2006). Perceptions of distance learning: A comparison of online and traditional learning. Journal of online learning and teaching, 2(1), 1-11.

32- Hartnett, M., St George, A., \& Dron, J. (2011). Examining motivation in online distance learning environments: Complex, multifaceted, and situation-dependent. International Review of Research in Open and Distributed Learning, 12(6), 20-38.

33- Haydn, T., \& Barton, R. (2008). 'First do no harm': Factors influencing teachers' ability and willingness to use ICT in their subject teaching. Computers \& Education, 51(1), 439-447. 
34- Hiranrithikorn, P. (2019, October). ADVANTAGES AND DISADVANTAGES OF ONLINE LEARNING. In INTERNATIONAL ACADEMIC MULTIDISCIPLINARY RESEARCH CONFERENCE IN BERLIN 2019 (pp. 14-17).

35- James, G. (2002). Advantages and disadvantages of online learning. Retrieved July 1, 2006. ad dis ol.doc.doc (leerbeleving.nl).

36- Khan, M. A., Nabi, M. K., Khojah, M., \& Tahir, M. (2021). Students' Perception towards E-Learning during COVID-19 Pandemic in India: An Empirical Study. Sustainability, 13(1), 57.

37- Khany, R., \& Ghoreyshi, M. (2013). Iranian EFL teachers' familiarity, attitudes, and willingness towards different Internet tools and their applications. European Online Journal of Natural and Social Sciences, 2(2s), pp-612.

38- Kim, K. J., \& Bonk, C. J. (2006). The future of online teaching and learning in higher education. Educause quarterly, 29(4), 22-30.

39- Kimura, N. (2020). Online Learning during the COVID-19 Pandemic: Social Interaction and Its Impacts on Student Satisfaction.

40- Kreijns, K., Vermeulen, M., Kirschner, P. A., Buuren, H. V., \& Acker, F. V. (2013). Adopting the Integrative Model of Behaviour Prediction to explain teachers' willingness to use ICT: a perspective for research on teachers' ICT usage in pedagogical practices.Technology, Pedagogy, and Education, 22(1), 55-71.

41- Kumar, D. (2010). Pros and cons of online education. Manuscript, North Carolina State University, Raleigh, NC, USA.

42- Kundu, A. (2018). A Study on Indian Teachers' Roles and Willingness to Accept Educational Technology.

43- Lippart, J. L. (2020). Incorporating ArcGIS Online in the Social Studies Classroom: Comparative Case Studies.

44- Mirkholikovna, D. K. (2020). Advantages and disadvantages of distance learning. Наука и образование сегодня, (7 (54).

45- Moore, J. L., Dickson-Deane, C., \& Galyen, K. (2011). e-Learning, online learning, and distance learning environments: Are they the same? The Internet and Higher Education, 14(2), 129-135.

46- Ouma, G. O., Awuor, F. M., \& Kyambo, B. (2013). E-Learning Readiness in Public Secondary Schools in Kenya. European Journal of Open, Distance and E-learning, 16(2), 97-110. 
47- Phoong, S. Y., Phoong, S. W., Moghawemi, S., \& Sulaiman, A. (2019). Effect of Smart Classroom on Student Achievement at Higher Education. Journal of Educational Technology Systems, 48(2), 291-304.

48- Radović-Marković, M. (2010). Advantages and disadvantages of e-learning in comparison to traditional forms of learning. Annals of the University of Petroşani, Economics, 10(2), 289-298.

49- Rovai, A. P., \& Baker, J. D. (2005). Gender differences in online learning: Sense of community, perceived learning, and interpersonal interactions. Quarterly Review of Distance Education, 6(1), 31.

50- Sharma, S., \& Parmar, J. S. (2017). FAMILY VARIABLES AND WORK-LIFE BALANCE-A STUDY OF DOCTORS IN GOVERNMENT HOSPITALS OF HIMACHAL PRADESH. Indian Journal of Commerce and Management Studies, 8(3), 106.

51- Sulaiman, A., \& Dashti, A. (2018). Students' satisfaction and factors in using Mobile learning among college students in Kuwait. EURASIA Journal of Mathematics, Science and Technology Education, 14(7), 3181-3189.

52- Taylor, R. W. (2002). Pros and cons of online learning-a faculty perspective. Journal of European Industrial Training.

53- Tsai, C. C., \& Chai, C. S. (2012). The" third"-order barrier for technologyintegration instruction: Implications for teacher education. Australasian Journal of Educational Technology, 28(6).

54- Wallace, R. M. (2003). Online learning in higher education: A review of research on interactions among teachers and students. Education, Communication \& Information, 3(2), 241-280.

55- Xu, D., \& Jaggars, S. S. (2013). The impact of online learning on students' course outcomes: Evidence from a large community and technical college system. Economics of Education Review, 37, 46-57.

56- Yukselturk, E., \& Bulut, S. (2009). Gender differences in self-regulated online learning environment. Journal of Educational Technology \& Society, 12(3), $12-22$.

57- Zhu, C., Valcke, M., \& Schellens, T. (2010). A cross-cultural study of teacher perspectives on teacher roles and adoption of online collaborative learning in higher education. European Journal of Teacher Education, 33(2), 147-165. 